\title{
CMAJ 2011 election survey: pharmacare
}

I $\mathrm{t}$ is a simple statement of fact that countries with national pharmacare programs, such as the United Kingdom, New Zealand, Australia, Sweden and France pay less for drugs and haven't experienced the kind of skyrocketing annual increases in drug outlays that have become common in Canada and the United States.

Organisation for Economic Cooperation and Development figures indicate that per capita drug costs (both public and private) in Canada were USD\$701 in 2008, behind only the United States, at US\$807, among OECD member nations (www.oecd.org /document/16/0,3343,en_2649_34631 _2085200_1_1_1_1,00.html).

By comparison, the 2008 US\$ per capita outlays of countries with pharmacare programs were substantially lower, including the United Kingdom (\$368), New Zealand (\$257), Sweden (\$457) and France (\$563). The 2007 figure for Australia was US\$480.

Fears that a national pharmacare program would be too costly, encroach upon provincial jurisdiction or somehow compromise the profit margins, and thus the health, of pharmaceutical and health insurance firms have long been advanced as reasons to avoid the introduction of universal drug coverage. But experts now say that the biggest barrier to a national pharmacare program has become a lack of political will (www.cmaj.ca/cgi/doi/10.1503/cmaj.109 -3869).

That's also evident in party responses to CMAJ's 2011 election survey, in which even the New Democrats, who have long championed national pharmacare, make no mention of the notion. Rather, they would focus their efforts on measures to promote bulk buying of drugs, evidence-based prescribing and reduced administration costs, while also undertaking "aggressive price reviews."

The Liberals essentially duck the universal pharmacare issue but indicate they will "work with the provinces and territories" to ensure Canadians have

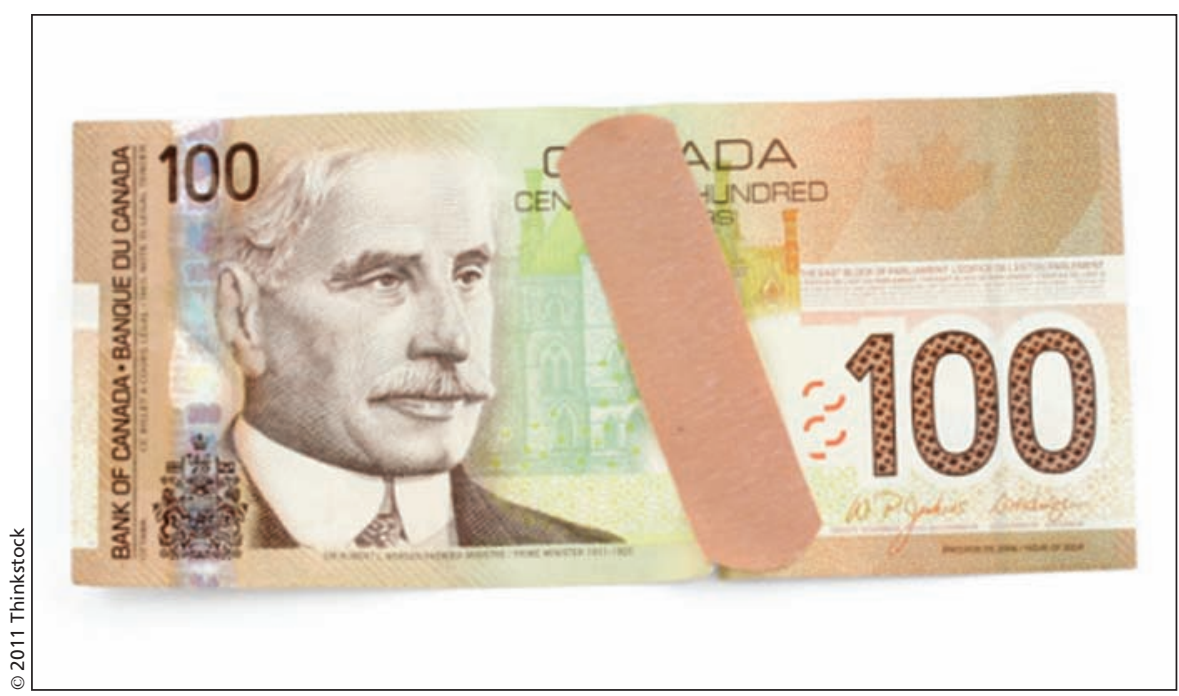

Health advocates say Canada's stance on universal drug coverage needs to be fixed to reduce skyrocketing drug costs but the political parties are proposing no more than band-aid solutions.

some manner of access to catastrophic drug programming. They would also "explore" bulk purchasing.

The Bloc Québécois basically says that Quebec already has what amounts to a pharmacare program and what happens in other parts of the country is essentially immaterial. As always, though, the Bloc ascribes Ottawa's role as correcting the fiscal imbalance by ponying up more cash for the provinces.

The Conservatives, meanwhile, declined to participate in the CMAJ survey, which is reminiscent of ex-Tory Prime Minister Kim Campbell's erstwhile assertion that elections are never a good time to discuss substantive issues.

The Tories said all policy can be answered by perusing their platform. But there is no mention of pharmaceuticals, prescriptions, catastrophic drug costs, formularies or any related term in the platform.

What use of the word "drugs" is contained within the platform is almost entirely within the context of illicit drug use, with the Tories repeatedly asserting that they "cracked down" on guns, gangs and drugs, or drug-impaired driving and plan to implement measures to similarly crackdown on illicit drug use in prisons. They also assert that they have "established the National AntiDrug Strategy, to help prevent illicit drug use and to support access to treatment for those with drug dependencies."

The only other mention of drugs is within the context of veterinary drugs, during which the Tories assert that retrograde Canadian regulations are preventing farmers from accessing the "best" veterinary drugs. - Wayne Kondro, CMAJ

Survey question: Will your party introduce a comprehensive national pharmacare program or a national catastrophic drug costs program?

\section{Conservative response:}

No response. Rather than participate in CMAJ's 2011 election survey, the Conservatives forwarded a weblink to their party platform. Asked what the rationale was for declining participation, party spokesperson Ryan Sparrow says the weblink constitutes a response to the survey. "That response is the response from the campaign."

\section{Liberal response:}

"The care that patients receive in hospitals is only one fraction of the treatment prescribed. Pharmaceutical drugs are 
becoming a greater and greater part of patient care. Drugs delivered in a hospital are covered by our healthcare system but those prescribed outside of the hospital are a different story.

Every province and territory has a different approach to dealing with the rising costs of pharmaceuticals. This makes the quality of care dependent upon your postal code. More than 3.5 million Canadians have inadequate drug coverage or no coverage at all.

A Liberal government, at the table for Canada, will work with the provinces and territories to ensure that all Canadians from coast-to-coast-to-coast have a drug plan that covers the cost of prescription drugs for illnesses such as cancer, diabetes or arthritis that can be financially catastrophic to families.

A Liberal government will also explore ways to lower the cost of prescription drugs for the healthcare system, including supporting provinces and territories to expand bulk purchasing."

New Democrat response:

"Jack Layton will work with the provinces and territories to save Canadians money on the cost of their prescription medications, including, as finances permit:
- Improved assessment to ensure quality, safety and cost and health effectiveness of prescription drugs;

- Using bargaining power in pharmaceutical purchases;

- Cutting administrative costs through public administration;

- Establishing science-based formularies and clinical guidelines to advance evidence-based practice by physicians;

- More aggressive price reviews;

- Moving towards more publicly funded research and development, driven by public priorities, not commercial profits."

\section{Bloc Québécois response:}

"En matière de régime d'assurancemaladie, le Québec s'est doté, depuis plus de 30 ans, d'un système public de santé et de services sociaux pour assurer la santé et le bien-être de ses citoyens. Au fil du temps, ce système, tout en conservant son caractère public, s'est enrichi de multiples avantages complémentaires dont l'objectif demeure d'assurer aux Québécoises et aux Québécois l'accessibilité aux soins et aux services requis par leur état de santé avec la meilleure qualité possible. Le Québec possède notamment depuis longtemps un régime d'assurance-médicaments très généreux.

Le Bloc Québécois, en tant que parti qui agit au Parlement canadien, n'a pas à exercer de pressions sur le gouvernement du Québec en matière d'accès aux médicaments puisque ce champ de compétence relève du gouvernement québécois. Notre parti incite plutôt le gouvernement fédéral à agir à l'intérieur de son champ d'action et donc à rehausser son effort financier en corrigeant le déséquilibre fiscal. Cela permettrait au Québec et aux provinces de financer plus adéquatement des programmes efficaces qui existent déjà. Si le gouvernement du Québec veut participer à une quelconque stratégie, il le fera de son propre gré et selon ses propres champs de compétence."

CMAJ 2011. DOI:10.1503/cmaj.109-3870

Editor's note: Second of a series of stories on $C M A J$ 's 2011 election survey:

Part 1: Health transfers (www.cmaj.ca /cgi/doi/10.1503/cmaj.109-3865) 